\title{
Perbedaan Pengetahuan dan Perilaku Membaca Label Pangan Antara Mahasiswa Prodi Gizi dan Non Gizi Di Sekolah Tinggi Ilmu Kesehatan Baiturrahim Jambi
}

\author{
Afriza Riyanti ${ }^{1}$, Dini Junita ${ }^{2}$, Elvin Rosalina ${ }^{2}$ \\ ${ }^{1-3}$ Program Studi SI Ilmu Gizi STIKes Baiturrahim Jambi \\ Email: afrizariyanti1997@gmail.com
}

Submitted : 31/03/2020

Accepted: 13/04/2020

Published: 07/09/2020

\begin{abstract}
The behavior of reading food labels is one of the Balanced Nutrition Messages. How to find out the safety of packaged food to be purchased by looking at food labels, but awareness of the importance of reading labels is still low. Nutrition students at STIKes Baiturrahim obtained courses related to food labeling and to make conclusions about the extent to which nutrition students understand and practice food labels, then a comparison group was made of non-nutrition students. The aim of this study was to found the differences in knowledge and behavior in reading food labels between nutrition and non-nutrition students at STIKes Baiturrahim. This study used a cross sectional study design that was conducted at STIKes Baiturrahim Jambi in May 2019. The research respondents were final year students at STIKes Baiturrahim from a group of 70 nutrition and non-nutrition students with a purposive sampling technique. Data collection uses a questionnaire about knowledge about food labels and food label reading behavior. Data were then analyzed using the Mann Whitney test for food label knowledge and the Independent Sample t-test for reading food label behavior. The results showed that there were no differences in knowledge and behavior in reading food labels between nutrition and non-nutrition students with p-values of each variable 0,203 and 0,554. For further research, it can be continued with the same or different variables by taking a variable on one of the food label information that is on food packaging with a more indepth research method (qualitative).
\end{abstract}

Keywords: behavior, food label, knowledge, non nutrition student, nutrition student

\begin{abstract}
Abstrak
Perilaku membaca label pangan merupakan salah satu dari Pesan Gizi Seimbang. Cara mengetahui keamanan pangan kemasan yang akan dibeli dengan melihat label pangan, namun kesadaran akan pentingnya membaca label masih rendah. Mahasiswa gizi di STIKes Baiturrahim memperoleh mata kuliah terkait label pangan dan untuk membuat kesimpulan mengenai sejauh mana pemahaman dan praktek mahasiswa gizi terhadap label pangan, maka dibuatlah satu kelompok perbandingan dari mahasiswa non gizi. Penelitian ini ingin melihat perbedaan pengetahuan dan perilaku membaca label pangan antara mahasiswa gizi dan non gizi di STIKes baiturrahim. Penelitian ini menggunakan desain cross sectional study yang dilaksanakan di STIKes Baiturrahim Jambi pada bulan Mei 2019. Responden penelitian merupakan mahasiswa tingkat akhir di STIKes Baiturrahim dari kelompok mahasiswa gizi dan non gizi sebanyak 70 responden dengan tehnik purposive sampling. Pengumpulan data menggunakan kuesioner tentang pengetahuan mengenai label pangan dan perilaku membaca label pangan. Data kemudian dianalisis menggunakan uji Mann Whitney untuk pengetahuan label pangan dan uji Indpendent sample t-test untuk perilaku membaca label pangan. Hasil penelitian diketahui bahwa tidak terdapat perbedaan pengetahuan dan perilaku membaca label pangan antara mahasiswa gizi dan non gizi dengan $p$ value masing-masing variabel 0,203 dan 0,554 . Bagi penelitian selanjutnya dapat dilanjutkan dengan variabel yang sama ataupun berbeda dengan mengambil variabel pada salah satu keterangan label pangan yang ada di kemasan pangan dengan metode penelitian yang lebih mendalam (kualitatif).
\end{abstract}

Kata kunci: label pangan, mahasiswa gizi, mahasiswa non gizi, pengetahuan, perilaku 


\section{PENDAHULUAN}

Kejadian penyakit tidak menular yang berkaitan dengan gizi terus meningkat di banyak negara di dunia. Hasil Riset Kesehatan Dasar (Riskesdas) Indonesia tahun 2013 menunjukkan adanya peningkatan prevalensi penyakit tidak menular seperti diabetes mellitus, hipertensi dan stroke di sebagian besar provinsi. Data Riskesdas Provinsi Jambi tahun 2013 pun menunjukkan adanya hal yang sama, yaitu terdapat peningkatan prevalensi hipertensi berdasarkan wawancara dari $7,6 \%$ tahun 2007 menjadi 9,5\% tahun 2013, hal yang sama untuk stroke berdasarkan wawancara juga meningkat dari 8,3 per 1000 pada tahun 2007 menjadi 12,1 per 1000 pada tahun 2013. Demikian juga untuk diabetes mellitus yang berdasarkan wawancara juga terjadi peningkatan dari $1,1 \%$ tahun 2007 menjadi 2,1\% tahun 2013. (Riskesdas, 2013). Peningkatan prevalensi penyakit tidak menular salah satunya disebabkan oleh pola makan yang tidak sehat. Perkembangan kebudayaan, ekonomi, industrialisasi dan teknologilah yang mendorong masyarakat untuk bergeser menuju kebiasaan baru, termasuk dalam pola konsumsi makanan. Masyarakat beralih memilih makanan siap saji dan makanan kemasan dengan alasan kepraktisan dan keterjangkauan (Palupi, dkk, 2017)

Konsumsi makanan kemasan oleh mahasiswa dalam hal ini mahasiswa tingkat akhir dengan usia >20 tahun yang tergolong ke masa peralihan dari remaja akhir ke dewasa merupakan hal yang lumrah. Hampir semua mengkonsumsi makanan kemasan paling sedikit satu bungkus/hari. Namun informasi-informasi yang terdapat pada makanan kemasan seperti yang tercantum pada label pangan sering luput dari perhatian konsumen. Hal ini didukung oleh data beberapa penelitian terkait label pangan dan hasil survey yang dilakukan oleh Badan Perlindungan Konsumen Nasional (BPKN) pada tahun
2007 menyebutkan bahwa hanya sebesar $6.7 \%$ konsumen di Indonesia yang memperhatikan kelengkapan label pangan suatu produk.

Sebagai salah satu pilar dari Pesan Gizi Seimbang (PGS), perilaku membaca label pangan dapat mendukung pola hidup sehat dengan membantu konsumen untuk menentukan pilihan bahan makanan yang akan dikonsumsi sehingga aman bagi kesehatan. Pencantuman informasi yang jelas dan benar pada label makanan kemasan akan memudahkan konsumen dalam memilih suatu produk pangan yang biasanya juga dipengaruhi oleh pengetahuan konsumen tentang label makanan kemasan (Almatsier, 2011).

Pengetahuan tentang label pangan merupakan bagian dari materi perkuliahan mahasiswa gizi di kurikulum pembelajaran pendidikan gizi. Sekolah Tinggi Ilmu Kesehatan Baiturahim merupakan salah satu institusi kesehatan yang didalamnya terdapat program studi (prodi) SI Gizi. Pemahaman dan pelaksanaan aturan yang telah ditetapkan mengenai label pangan seharusnya dijalankan oleh setiap orang, khususnya mahasiswa gizi. Mahasiswa sebagai civitas akademika diharapkan mampu memahami, mengawasi, dan mengaplikasikan ilmu yang telah didapatkan sebagai contoh yang baik bagi masyarakat. Hal tersebut dapat tercermin melalui pengetahuan yang baik mengenai label pangan serta patuh terhadap membaca label pangan dan dapat mengaplikasikan pengetahuan tersebut dalam kehidupan sehari-hari. Untuk membuat kesimpulan mengenai sejauh mana pemahaman dan praktek mahasiswa prodi gizi terhadap label pangan dibuatlah satu kelompok perbandingan dari non gizi untuk melihat perbedaan pengetahuan dan perilaku dalam membaca label pangan. Pengetahuan yang baik menentukan motivasi seseorang untuk mengimplementasikan perilaku tertentu, termasuk dalam hal perilaku membaca label pangan. 
Penelitian ini bertujuan untuk mengetahui perbedaan pengetahuan label pangan dan perilaku membaca label pangan antara mahasiswa gizi dan non gizi di STIKes Baiturrahim.

\section{METODE PENELITIAN}

Penelitian ini dilaksanakan dengan menggunakan desain cross sectional untuk mengetahui perbedaan pengetahuan dan perilaku membaca label pangan antara mahasiswa gizi dan non gizi. Subjek penelitian diambil dengan cara purposive sampling yang disesuaikan dengan kriteria penelitian. Responden penelitian berjumlah 70 responden yang berasal dari kelompok mahasiswa gizi dan non gizi. Kelompok gizi yaitu mahasiswa yang berasal dari program studi SI Ilmu gizi, sedangkan kelompok non gizi yaitu mahasiswa yang berasal dari program studi SI Keperawatam, DIII Kebidanan, DIII Fisioterapi dan DIII Keperawatan. Penelitian ini dilaksanakan pada bulan Mei 2019

Data identitas responden diperoleh melalui pengisian kuesioner oleh responden. Variabel yang diteliti meliputi pengetahuan label pangan dan perilaku membaca label pangan. Pengetahuan label pangan merupakan kemampuan responden dalam menentukan segala sesuatu yang diketahui tentang label pangan terkait pengertian, tujuan pelabelan dan jenis informasi yang terdapat dalam label pangan. Pengambilan data menggunakan kuesioner pengetahuan dengan bentuk pertanyaan benar atau salah berjumlah 20 soal, skor 1 untuk jawaban benar dan skor 0 untuk jawaban salah, dikategorikan menjadi pengetahuan baik ( $\geq$ median : 15) dan pengetahuan kurang baik (<median : 15). Perilaku membaca label pangan merupakan kebiasaan responden dalam membaca label pangan kemasan meliputi pertanyaan terkait kepatuhan membaca keterangan minimum yang wajib dicantumkan dalam kemasan pangan, membaca keterangan informasi nilai gizi, kecenderungan untuk tidak membeli kemasan pangan yang tidak mencantumkan keterangan minimum yang wajib. Pengambilan data menggunakan kuesioner perilaku membaca label pangan yang berisi 25 pertanyaan dengan skala likert. Rentang skala yang digunakan yaitu 1 (tidak pernah) sampai 4 (selalu) dengan total skor 25-100. Dikategorikan menjadi 2 yaitu perilaku baik jika skor jawaban $\geq$ mean (64,80 untuk mahasiswa gizi dan 66,50 untuk mahasiswa non gizi), dan perilaku kurang baik jika skor jawaban $<$ mean.

Pengolahan data diawali dengan pemeriksaan kelengkapan kuesioner data kemudian mengolah dan menganalisis data berdasarkan kategori pengukuran masingmasing dengan menggunakan program komputer secara univariat dan bivariat. Analisis univariat dilakukan untuk mendeskripsikan masing-masing variabel. Data kemudian diuji normalitasnya dengan Shapiro-wilk. Analisis bivariat dilakukan untuk melihat beda antara masing-masing variabel per kelompok gizi dan non gizi menggunakan uji Independent sample t-test untuk perilaku membaca label pangan dan uji mann whitney untuk pengetahuan label pangan.

\section{HASIL DAN PEMBAHASAN Gambaran umum responden}

Mahasiswa yang dijadikan responden dalam penelitian ini adalah mahasiswa aktif tingkat akhir yang ada di STIKes Baiturrahim. Hasil analisis univariat menggambarkan bahwa sebagian besar responden dari kedua kelompok berusia 22 tahun. Jumlah responden perempuan lebih banyak dibandingkan responden laki-laki. Data lengkap masing-masing karakteristik dapat dilihat pada tabel 1 . 
Tabel 1 Karakteristik responden

\begin{tabular}{|c|c|c|c|c|}
\hline \multirow[t]{2}{*}{ Karakteristik } & \multicolumn{2}{|c|}{$\begin{array}{l}\text { Mahasiswa } \\
\text { gizi }\end{array}$} & \multicolumn{2}{|c|}{$\begin{array}{c}\text { Mahasiswa } \\
\text { non gizi }\end{array}$} \\
\hline & $\mathrm{n}$ & $\%$ & $\mathrm{n}$ & $\%$ \\
\hline \multicolumn{5}{|l|}{ Usia } \\
\hline 20 th & 1 & 2,8 & 6 & 17,1 \\
\hline 21 th & 15 & 42,8 & 10 & 28,5 \\
\hline 22 th & 16 & 45,7 & 15 & 42,8 \\
\hline 23 th & 2 & 5,7 & 3 & 8,5 \\
\hline 25 th & 0 & 0 & 1 & 2,8 \\
\hline 26 th & 1 & 2,8 & 0 & 0 \\
\hline \multicolumn{5}{|l|}{ Jenis kelamin } \\
\hline Laki-laki & 2 & 5,7 & 6 & 17,1 \\
\hline Perempuan & 33 & 94,3 & 29 & 82,9 \\
\hline
\end{tabular}

Sebaran usia responden dalam penelitian ini ada di rentang 20-26 tahun yang tergolong ke klasifikasi usia dewasa muda. Menurut Febry, dkk (2013) usia dewasa merupakan usia yang matang dalam menentukan informasi yang dapat mempengaruhi suatu tindakan kesehatan, karena semakin bertambah usia maka akan terjadi peningkatan kemampuan untuk menerima informasi yang berpengaruh terhadap peningkatan pola pikir dan daya terima terhadap informasi.

\section{Sumber informasi mendapatkan label pangan}

Informasi merupakan segala sesuatu berupa data ataupun fakta yang memiliki manfaat bagi penerimanya, tidak ada batasan karena informasi dapat dengan mudah diakses melalui apa saja.

Sumber informasi yang didapatkan mengenai label pangan pada mahasiswa gizi paling banyak dipengaruhi oleh media yaitu sebesar 47,3\%, selanjutnya diikuti dengan pengetahuan yang diterima di perkuliahan yaitu sebesar 33,3\%, serta sisanya di dapat dari informasi teman $(12,3 \%)$ dan membaca buku sebesar (7\%). Sementara untuk mahasiswa non gizi, sumber informasi tentang label pangan hanya didapat dari media $(94,6 \%)$ dan informasi perkuliahan (5,4\%). Hasil penelitian ini dan ketiga penelitian lain terkait label pangan, yaitu penelitian Purnama (2012), Birri, M (2014) dan Santosa (2014) menunjukkan bahwa sebagian besar responden memperoleh informasi mengenai label pangan yang berasal dari media.

\section{Prioritas keterangan label pangan}

Ada banyak keterangan pada label pangan yang dapat ditemukan di produk kemasan pangan. Keterangan yang ditanyakan meliputi keterangan minimum yang wajib dicantumkan yaitu nama produk, alamat produk, komposisi bahan pangan, berat bersih dan tanggal kadaluarsa. Selain itu, keterangan lain mengenai informasi nilai gizi, keterangan halal, cara penyimpanan, kode produksi dan informasi allergen juga ditanyakan pada kuesioner. Urutan prioritas keterangan label pangan terlihat pada tabel 2 berikut.

Tabel 2 Priotitas keterangan label dalam memilih produk

\begin{tabular}{|c|c|c|c|c|}
\hline Prioritas & $\begin{array}{l}\text { Mahasiswa } \\
\text { gizi }\end{array}$ & $\%$ & $\begin{array}{c}\text { Mahasiswa } \\
\text { non gizi }\end{array}$ & $\%$ \\
\hline 1 & $\begin{array}{l}\text { Nama } \\
\text { produk }\end{array}$ & 16,5 & $\begin{array}{l}\text { Keterangan } \\
\text { halal }\end{array}$ & 15,1 \\
\hline 2 & $\begin{array}{l}\text { Keterangan } \\
\text { halal }\end{array}$ & 14,9 & Nama produk & 13,9 \\
\hline 3 & $\begin{array}{l}\text { Tanggal } \\
\text { kadaluarsa }\end{array}$ & 14,4 & $\begin{array}{l}\text { Tanggal } \\
\text { kadaluarsa }\end{array}$ & 13,2 \\
\hline 4 & $\begin{array}{l}\text { Informasi } \\
\text { nilai gizi }\end{array}$ & 11,8 & $\begin{array}{l}\text { Komposisi } \\
\text { bahan pangan }\end{array}$ & 12,4 \\
\hline 5 & $\begin{array}{l}\text { Komposisi } \\
\text { bahan } \\
\text { pangan }\end{array}$ & 11,5 & $\begin{array}{l}\text { Informasi nilai } \\
\text { gizi }\end{array}$ & 10,4 \\
\hline 6 & Berat bersih & 9,2 & Berat bersih & 9 \\
\hline 7 & $\begin{array}{l}\text { Informasi } \\
\text { allergen }\end{array}$ & 5,7 & Alamat produk & 7,3 \\
\hline 8 & $\begin{array}{l}\text { Cara } \\
\text { penyimpanan }\end{array}$ & 5,6 & $\begin{array}{l}\text { Cara } \\
\text { penyimpanan }\end{array}$ & 6,7 \\
\hline 9 & $\begin{array}{l}\text { Kode } \\
\text { produksi }\end{array}$ & 5,2 & $\begin{array}{l}\text { Informasi } \\
\text { allergen }\end{array}$ & 6,3 \\
\hline 10 & $\begin{array}{l}\text { Alamat } \\
\text { produk }\end{array}$ & 5,1 & Kode produksi & 5,3 \\
\hline
\end{tabular}

Keterangan label yang pertama kali diperhatikan mahasiswa gizi yaitu nama produk dan alamat produk di urutan terakhir, sedangkan pada mahasiswa non gizi yang pertama diperhatikan yaitu keterangan halal dan informasi allergen di urutan terakhir. Nama produk menjadi prioritas pertama yang diperhatikan mahasiswa gizi, hal ini dapat terjadi karena sebagian besar responden menganggap 
nama produk sebagai gambaran dari apa yang ada di dalam kemasan. Hal ini sejalan dengan penelitian Pane, PS (2016) terhadap mahasiswa gizi di Institut Pertanian Bogor (IPB) bahwa hampir setengah jumlah responden yaitu $46,67 \%$ memilih untuk membaca keterangan nama produk terlebih dahulu.

Keterangan halal menjadi prioritas pertama yang diperhatikan mahasiswa non gizi, hal ini dapat terjadi karena responden yang menjadi subjek penelitian beragama Islam sehingga kehalalan dari suatu produk menjadi keharusan yang wajib diutamakan. Selain itu, didukung juga oleh latar belakang Sekolah Tinggi Ilmu Kesehatan Baiturrahim yang merupakan salah satu perguruan tinggi yang menjunjung tinggi nilai-nilai islami. Penelitian ini sejalan dengan penelitian Birri, M (2014) terhadap mahasiswa fakultas pertanian di Universitas Syiah Kuala, Aceh yang mayoritas responden beragama Islam menunjukkan hasil bahwa $41 \%$ responden memilih label halal di prioritas pertama dan tanggal kadaluarsa (36\%) di prioritas kedua.

\section{Gambaran pengetahuan label pangan}

Informasi yang jelas dan benar yang terdapat pada label pangan kemasan akan memudahkan seseorang dalam memilih suatu produk pangan yang biasanya didasari pula oleh pengetahuan tentang label pangan. Informasi yang terdapat di dalam label pangan penting untuk diketahui karena dapat mengetahui kandungan gizi dan kelayakan pangan kemasan tersebut. Sebaran pengetahuan label pangan mahasiswa gizi dan non gizi terlihat pada tabel 3 .

Persentase terbesar $74,3 \%$ responden mahasiswa gizi berada pada kategori pengetahuan baik, sedangkan pada mahasiswa non gizi responden yang memiliki pengetahuan baik sebesar $62,9 \%$. Skor maksimal untuk pengetahuan label pangan adalah 20. Nilai rata-rata skor pengetahuan label pangan mahasiswa gizi sebesar 14,9, sedangkan pada mahasiswa non gizi sebesar 14,6.

Tabel 3. Sebaran pengetahuan label pangan pada mahasiswa gizi dan non gizi

\begin{tabular}{cccc}
\hline $\begin{array}{c}\text { Pengetahuan label } \\
\text { pangan }\end{array}$ & \multicolumn{3}{c}{ Mahasiswa gizi } \\
& $\mathrm{n}$ & $\%$ & Mean \\
\hline Baik & 26 & 74.3 & 14.9 \\
Kurang baik & 9 & 25.7 & \\
\hline \multirow{2}{*}{$\begin{array}{c}\text { Pengetahuan label } \\
\text { pangan }\end{array}$} & \multicolumn{3}{c}{ Mahasiswa non gizi } \\
\hline Baik & 22 & $\%$ & Mean \\
Kurang baik & 13 & 37.14 & 14.6 \\
\hline
\end{tabular}

Jawaban dari pertanyaan tentang pengetahuan label pangan masih banyak yang salah. Terdapat 5 pertanyaan yang banyak dijawab salah oleh sebagian besar responden, antara lain satuan berat bersih, pengertian berat bersih, pengertian daftar bahan penyusun makanan, informasi gizi tidak harus dicantumkan, dan nama produk yang harus menggunakan bahasa Indonesia.

\section{Gambaran perilaku membaca label pangan}

Perilaku membaca label pangan merupakan kebiasaan responden dalam membaca keterangan label pangan. Pernyataan yang diajukan dibuat dalam pernyataan positif, meliputi kebiasaan membaca keterangan minimum yang wajib dicantumkan dalam kemasan pangan, membaca keterangan informasi nilai gizi, kecenderungan untuk tidak membeli makanan kemasan yang tidak mencantumkan keterangan minimum yang wajib, dan sebagainya. Sebaran perilaku membaca label pangan mahasiswa gizi dan non gizi terlihat pada tabel 4 . 
Tabel 4 Sebaran perilaku membaca label pangan pada mahasiswa gizi dan non gizi

\begin{tabular}{cccc}
\hline $\begin{array}{c}\text { Perilaku } \\
\text { membaca label } \\
\text { pangan }\end{array}$ & \multicolumn{3}{c}{ Mahasiswa gizi } \\
& $\mathrm{N}$ & $\%$ & Mean \\
\hline Baik & 18 & 51,4 & 64,8 \\
Kurang baik & 17 & 48,6 & \\
\hline Perilaku & \multicolumn{3}{c}{ Mahasiswa non gizi } \\
$\begin{array}{c}\text { membaca label } \\
\text { pangan }\end{array}$ & $\mathrm{n}$ & $\%$ & Mean \\
\hline Baik & 15 & 42,9 & 66,5 \\
Kurang baik & 20 & 57,1 & \\
\hline
\end{tabular}

Persentase terbesar $51,4 \%$ perilaku membaca label pangan mahasiswa gizi berada pada kategori baik, sedangkan pada mahasiswa non gizi lebih banyak responden yang memiliki perilaku membaca label pangan kurang baik. Nilai rata-rata skor perilaku membaca label pangan mahasiswa gizi sebesar 64,8, sedangkan pada mahasiswa non gizi sebesar 66,5 dari skor maksimal yaitu 100. Hal yang menjadi masalah dalam hal ini adalah terkait perilaku membaca label pangan mahasiswa non gizi. Sebanyak $57,1 \%$ responden mahasiswa non gizi memiliki perilaku membaca label pangan yang kurang baik. Menurut Signal, dkk (2008) ada beberapa hal yang mungkin menjadi alasan seseorang tidak memperhatikan label pangan. Alasan tersebut diantaranya keterangan label pangan yang tidak menarik perhatian, tidak ada waktu untuk membaca, keterbatasan memahami informasi yang tertera pada label, dan kurang peduli terhadap pangan yang dikonsumsi. Hal lain yang mungkin menjadi alasan responden tidak memperhatikan label pangan, menurut Samson (2012) adalah karena produk tersebut tidak asing bagi mereka.

Terdapat beberapa pertanyaan dengan skor rendah, artinya perilaku pada pertanyaan tersebut jarang dilakukan oleh responden. Pada mahasiswa gizi perilaku tersebut terkait membaca keterangan persentase natrium, membaca keterangan persentase AKG vitamin dan mineral dan menyatakan protes apabila keterangan label produk tidak sesuai dengan ketentuan. Sedangkan pada mahasiswa non gizi perilaku yang jarang dilakukan terkait membaca keterangan informasi nilai gizi (persentase lemak total, persentase natrium, keterangan takaran saji dan keterangan persentase jumlah sajian). Menurut Grunet, dkk (2007) dalam Nurcahya, AS (2014) sikap terhadap kesehatan dan label pangan berhubungan erat dengan kepentingan seseorang dalam gizi, semakin banyak orang yang sadar akan kesehatan semakin besar kemungkinan mereka untuk menggunakan informasi gizi.

\section{Perbedaan pengetahuan label pangan mahasiswa gizi dan non gizi}

Hasil analisis uji beda pengetahuan label pangan mahasiswa gizi dan non gizi terlihat pada tabel 5 .

Tabel 5. Perbedaan pengetahuan label pangan mahasiswa gizi dan non gizi

\begin{tabular}{cccccc}
\hline $\begin{array}{c}\text { Pengetahuan } \\
\text { label pangan }\end{array}$ & $\begin{array}{c}\text { Mahasiswa } \\
\text { gizi }\end{array}$ & $\begin{array}{c}\text { Mahasiswa } \\
\text { non gizi }\end{array}$ & $\begin{array}{c}P- \\
\text { value }\end{array}$ \\
\cline { 2 - 5 } & $\mathrm{n}$ & $\%$ & $\mathrm{n}$ & $\%$ & \\
\hline Baik & 26 & 74,3 & 22 & 62,9 & 0,203 \\
Kurang baik & 9 & 25,7 & 13 & 37,1 & \\
\hline
\end{tabular}

Dalam penelitian ini sebagian besar sampel dari kedua kelompok memiliki pengetahuan label pangan yang baik, namun mahasiswa yang mempunyai pengetahuan kurang baik lebih banyak berasal dari mahasiswa non gizi dibanding mahasiswa gizi. Hal ini dapat disebabkan latar belakang pendidikan yang didapatkan saat perkuliahan. Sebagai mahasiswa gizi tentunya mereka memiliki pengetahuan yang lebih baik karena mendapatkan mata kuliah mengenai gizi dan segala sesuatu yang dipelajari tidak jauh dari permasalahan gizi. Hal ini didukung oleh hasil penelitian yang terdapat pada grafik 4.1 mengenai sumber informasi mengenai label pangan, sebanyak 33,3\% responden dari kelompok mahasiswa gizi menyatakan memperoleh informasi mengenai label 
pangan saat perkuliahan. Mahasiswa gizi lebih banyak terpapar informasi mengenai label pangan karena memperoleh pendidikan mengenai gizi dan ada satu mata kuliah yang membahas materi terkait label pangan sehingga pengetahuannya tentang label pangannya lebih baik jika dibandingkan dengan mahasiswa non gizi.

Meskipun berdasarkan nilai aktual persentase kategori pengetahuan mahasiswa gizi lebih baik dari mahasiswa non gizi, namun hasil uji statistik diperoleh nilai $p$ value 0,203 yang artinya tidak terdapat perbedaan signifikan pengetahuan label pangan antara mahasiswa gizi dan non gizi. Hal ini dapat terjadi karena dilihat dari data hasil karakteristik responden, sebagian besar responden dari mahasiswa gizi dan non gizi berjenis kelamin perempuan. Beberapa penelitian terkait label pangan yang ada di studi literatur yang dilakukan oleh Sumarwan, dkk (2014) menunjukkan hasil bahwa perempuan lebih memungkinkan untuk memperhatikan label dibanding laki-laki. Selain itu keterpaparan sumber informasi mengenai label pangan dapat diperoleh dari mana saja, seperti internet, iklan, buku ataupun informasi dari teman (grafik 4.1). Keterpaparan informasi dari media seperti internet dan iklan televisi serta kemudahan akses dalam pencarian segala informasi di internet terkait label pangan memungkinkan mahasiswa dari kelompok non gizi memiliki pengetahuan akan hal tersebut. Latar belakang pendidikan dari kedua kelompok yang berasal dari kesehatan memungkinkan mahasiswa dari kelompok non gizi juga memperoleh informasi berkaitan dengan gizi dan kesehatan. Mahasiswa sebagai konsumen dengan tingkat pendidikan dan intelektual tinggi dapat lebih mudah mengakses informasi serta lebih terpapar informasi.

Informasi menurut Raymond Mc.Leod (2001) adalah data yang telah diolah menjadi bentuk yang memiliki arti bagi penerima dan bermanfaat bagi pengambilan keputusan saat ini atau mendatang. Informasi berguna untuk membuat keputusan karena informasi menurunkan ketidakpastian dan meningkatkan pengetahuan.

\section{Perbedaan perilaku membaca label pangan mahasiswa gizi dan non gizi}

Perilaku membaca label pangan merupakan salah satu dari Pesan Gizi Seimbang (PGS) karena salah satu cara untuk mengetahui keamanan pangan yang akan dibeli ialah dengan melihat label kemasan. Keamanan pangan merupakan salah satu aspek penting yang harus diperhatikan setiap orang untuk hidup sehat dan aman. Pangan yang aman dan bergizi serta bermutu tinggi berperan penting bagi pertumbuhan, pemeliharaan dan peningkatan kecerdasan serta derajat kesehatan masyarakat (Saparinto, 2006 dalam Pane Ps 2016). Hasil analisis uji beda pengetahuan label pangan mahasiswa gizi dan non gizi terlihat pada tabel 6 .

Tabel 6 Perbedaan perilaku membaca label pangan mahasiswa gizi dan non gizi

\begin{tabular}{cccccc}
\hline $\begin{array}{c}\text { Perilaku } \\
\text { membaca } \\
\text { label }\end{array}$ & $\begin{array}{c}\text { Mahasiswa } \\
\text { gizi }\end{array}$ & $\begin{array}{c}\text { Mahasiswa } \\
\text { non gizi }\end{array}$ & $\begin{array}{c}P \text { - } \\
\text { value }\end{array}$ \\
\cline { 2 - 5 } pangan & $\mathrm{n}$ & $\%$ & $\mathrm{n}$ & $\%$ & \\
\hline Baik & 18 & 51,4 & 15 & 42,9 & 0,554 \\
Kurang baik & 17 & 48,6 & 20 & 57,1 & \\
\hline
\end{tabular}

Dalam penelitian ini sebagian besar sampel mahasiswa gizi memiliki perilaku membaca label pangan yang baik, sebaliknya sebagian besar sampel mahasiswa non gizi memiliki perilaku membaca label pangan yang kurang baik. Hal ini dapat terjadi karena perbedaan materi yang didapatkan selama perkuliahan. Mahasiswa gizi selalu mendapatkan mata kuliah mengenai gizi dan segala sesuatu yang dipelajari tidak jauh dari permasalahan gizi dan kesehatan khususnya tentang label pangan. Selain itu, terlihat pada pembahasan tabel 6 , bahwa sebagian besar responden mahasiswa non gizi jarang membaca keterangan terkait informasi nilai 
gizi di kemasan pangan. Hal ini dapat disebabkan karena yang lebih banyak mendapatkan informasi selama perkuliahan terkait zat gizi dalam makanan adalah mahasiswa gizi. Menurut Sudahono (2014) pengetahuan terutama mengenai gizi seimbang dan cara membaca label merupakan salah satu hal yang berpengaruh terhadap pembacaan label makanan. Pengetahuan menumbuhkan motivasi untuk membaca label serta menjadi tuntunan ketika membaca label, sehingga konsumen tidak hanya membaca namun juga memahami apa yang dibaca.

Meskipun berdasarkan nilai aktual persentase kategori perilaku membaca label pangan mahasiswa gizi lebih baik dari mahasiswa non gizi, namun hasil uji statistik diperoleh nilai $p$-value 0,554 yang artinya tidak terdapat perbedaan signifikan perilaku membaca label pangan antara mahasiswa gizi dan non gizi. Seseorang dengan pendidikan tinggi, diharapkan luas pula pendidikannya dalam hal ini mengenai label pangan, dikarenakan latar belakang STIKes Baiturrahim yang merupakan salah satu kampus kesehatan. Informasi yang diperoleh baik dari pendidikan formal maupun non formal dapat memberikan pengaruh jangka pendek sehingga menghasilkan perubahan atau peningkatan pengetahuan. Dengan adanya pengetahuan, diharapkan dapat mempengaruhi perilaku seseorang dalam hal ini perilaku membaca label pangan. Menurut Dirchoutis, dkk (2006) sumber informasi mempunyai dampak positif pada seseorang yang membaca label pangan. Seseorang yang membaca label pangan akan menemukan informasi mengenai produk pangan dan dapat menentukan produk pangan yang sesuai dengan kebutuhannya.

Kebiasaan ataupun perilaku membaca label pangan memiliki dampak positif dalam mencegah konsumsi pangan yang tidak aman. Kebiasaan seseorang dalam melakukan sesuatu merupakan cerminan perilaku yang dapat terbentuk melalui faktor-faktor seperti pengetahuan. Perilaku membaca label pangan merupakan suatu indikator untuk mengetahui kebiasaan responden dalam membaca label pangan kemasan. Perilaku membaca label pangan yang baik dapat dilihat melalui kebiasaan responden membaca keterangan-keterangan minimum yang harus tercantum pada pangan kemasan (Pane,PS ,2016).

\section{SIMPULAN}

Berdasarkan penelitian ini diketahui tidak terdapat perbedaan dalam hal pengetahuan dan perilaku membaca label pangan antara mahasiswa gizi dan non gizi pada mahasiswa STIKes Baiturrahim. Hasil penelitian menunjukkan bahwa perilaku membaca label pangan mahasiswa non gizi sebagian besar masih kurang baik. Oleh karena itu, kebiasaan dalam membaca label pangan yang tertera di produk pangan perlu ditingkatkan bagi semua mahasiswa terutama mahasiswa non gizi. Perilaku membaca label pangan penting dilakukan terutama terkait keterangan yang selalu berubah seperti tanggal kadaluarsa dan terkait persentase zat-zat gizi yang ada di informasi nilai gizi, karena berkaitan dengan keamanan pangan dan resiko kesehatan. Penelitian ini belum membedakan jenis media sebagai sumber memperoleh informasi label pangan. Oleh karena itu, adanya klasifikasi media sebagai sumber informasi dapat menjadi pertimbangan pada penelitian selanjutnya. Penelitian ini dapat dilanjutkan dengan variabel yang sama ataupun berbeda, misalnya dengan mengambil variabel pada salah satu dari keterangan label pangan yang ada di pangan kemasan, dengan metode penelitian yang lebih mendalam.

\section{DAFTAR PUSTAKA}

Almatsier, Sunita. 2011. Prinsip Dasar Ilmu Gizi. Jakarta : PT. Gramedia Pustaka Utama.

Birri, M. 2014. Pengaruh perhatian label kemasan pangan terhadap keputusan 
mahasiswa dalam membeli makanan ringan di kota Banda Aceh. (skripsi) . Fakultas Pertanian Universitas Syiah Kuala Darussalam Banda Aceh

BPKN Depdag RI. 2007. Hasil Kajian Badan Perlindungan Konsumen Nasional (BPKN) di Bidang Pangan terkait Perlindungan Konsumen. Jakarta: Kementerian Perdagangan.

Dirchoutis, AC, dkk. 2006. Consumers' use of nutritional labels: a review of research studies and issues. Dalam: Article in academy of marketing science review, volume 2006 no. 9

Febry, Ayu bulan, Nurul P dan Ibnu F. 2013. Ilmu gizi untuk praktisi kesehatan. Yogyakarta: Graha Ilmu.

Kemenkes RI. 2013. Riset Kesehatan Dasar (Riskesdas). Jambi: Balitbang Provinsi Jambi

Kementrian Kesehatan RI. 2014. Riset Kesehatan Dasar (RISKESDAS 2013 ). Jakarta. Badan Penelitian dan Pengembangan Kesehatan Kementerian Kesehatan RI.

Mcleod, Raymond. 2001. Sistem informasi manajemen. Jakarta: PT. Prenhallindo

Nurcahya, AS dan Indrawani, YM. 2014. Keterpaparan informasi mengenai iklan pangan, kebiasaan membaca label pangan dan faktor-faktor hubungannya. FKM UI

Pane, PS. 2016. Analisis tingkat kepatuhan membaca label pangan pada mahasiswa gizi Institut Pertanian Bogor. (skripsi). Fakultas Ekologi Manusia IPB: Institut Pertanian Bogor

Purnama AS. 2012. Hubungan antara kemampuan membaca label informasi nilai gizi, persepsi terhadap rasa produk dan faktor lain dengan kepatuhan membaca label informasi nilai gizi pada siswa/i SMK Mandahalayu Bekasi tahun 2012. [skripsi]. Fakultas Kesehatan Masyarakat (SKM) UI: Universitas Indonesia.
Samson. 2012. Awareness of food labeling and use of the information in Purchasing food package food products among consumer in Ilala Municipality-Dar Es Sallam. (disertasi). Tanzania (SA): Master of Public Health Dissertation Muhimbili University

Signal, dkk. 2008. Perceptions of New Zealand nutrition labels by Maori, Pacific and low income shoppers. Journal of Public Health Nutrition. 11(7): 706-713

Sudahono, N dan Indrawani, YM. 2014. Gambaran perilaku membaca label pangan dan pengetahuan gizi pada mahasiswa jenjang sarjana reguler Fakultas Kesehatan Masyarakat Universitas Indonesia angkatan 2013. FKM UI

Sumarwan, dkk. 2017. Meta-Analysis Study: Reading behavior of food products label. Journal of consumer sciences. 2017, vol.02: 26-40 